\title{
Betraktninger fra frontlinjen
}

\begin{abstract}
«Tekno-medisinen, til sammenlikning, tilbyr oss en drømmeverden uten flertydighet, et vitenskapelig paradis hvor alt gir mening, ett sted hvor nesten alt kan måles og oversettes til tallenes språk. Dette er en utopi, hvor vitenskap erstatter åndelighet, hvor det ikke er rom for usikkerhet [...] både flertydighet og usikkerhet vil alltid vare del av enhver form for medisinsk praksis.»
\end{abstract}

(Utdrag fra Suburban shaman)

Cecil G. Helman (1944-2009) var lege og professor i medisinsk antropologi ved Brunel University og var tilknyttet Department of Primary Care and Population Sciences, University College London, England. Han døde av amyotrofisk lateral sklerose i juni 2009. Helman har gitt viktige bidrag til medisinen som forsker, forfatter og formidler.

\section{Helse og sykdom i kulturelt perspektiv}

Helman fattet interesse for skjæringsfeltet mellom kultur, sykdom og helse som ung lege og tok fatt på studier i sosialantropologi ved University College London tidlig i 1970-årene. Medisinsk antropologi er et fag med tradisjoner tilbake til slutten på 1800 -tallet da den britiske psykiateren, nevrologen og antropologen W.H.R. Rivers (1864-1922) begynte å interessere seg for hvordan sykdom ble forstått og håndtert i ulike øysamfunn i Torresstredet, mellom Australia og Ny-Guinea (1). De siste tiår er faget etablert ved en rekke medisinske lære- steder $(2,3)$, noe som ikke var tilfelle da Helman gjorde sine første kvalitative studier i allmennpraksis. Han forsket bl.a. på pasienters oppfatninger om legemidler (4), og bidro med dette til å rette søkelyset mot helsekulturen i vestlige samfunn. I den klassiske artikkelen «Feed a cold, starve a fever» fra 1978 beskrev han en folkelig sykdomsmodell for luftveisinfeksjoner, basert på subjektiv opplevelse av kroppstemperatur, som er noe annet enn målbar feber (5). Dette arbeidet viser at pasienters sykdomsoppfatning (illness) er et viktig medisinsk studiefelt i tillegg til kunnskap om selve sykdommen (disease), bl.a. fordi sykdomsoppfatningen innvirker på pasienters legesøkning og forventninger til helsetjenesten. I 1984 utga Helman læreboken Culture, health and illness som siden er kommet i nye, reviderte utgaver, sist i 2007 (6). Verket gir en god innføring i studier av helse og sykdom $i$ et kulturelt perspektiv, og det er orientert mot klinisk og samfunnsmedisinsk anvendelse av antropologisk kunnskap. Helman har utgitt essays om myter knyttet til kropp og sykdom (7), og i 2008 kom antologien Medical anthropo$\operatorname{logy}(8)$. Han interesserte seg også for feltet litteratur og medisin og utga en samling med litterære tekster om sykdom, pasienter og leger (9).

\section{Minnemosaikk}

I boken Suburban shaman (2006) gir Helman tydeligere uttrykk for sitt eget syn og ståsted enn i lærebøkene han har skrevet. Det er en «mosiakk av minner» som omhandler hans faglige liv, men der han
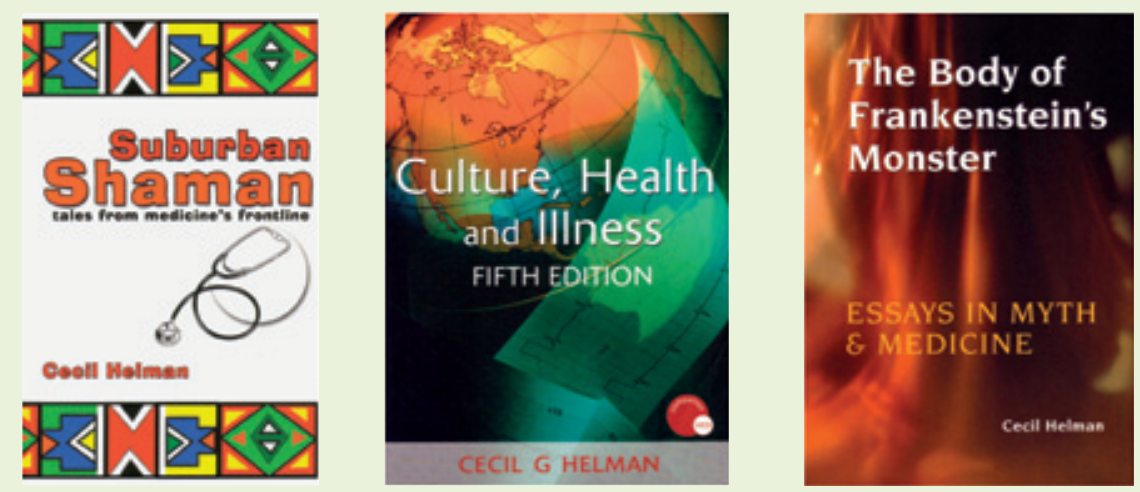

samtidig gransker vår tids medisin med et diagnostisk og kritisk blikk. Vi vil her gi et riss av hva teksten har å by på. Bokens første del omhandler Helmans år som medisinstudent ved University of Cape Town i Sør-Afrika. Den andre delen inneholder observasjoner og beretninger fra hans 27 år i allmennpraksis i London, og i den siste delen rettes søkelyset mot utviklingstrekk innen moderne medisin.

\section{Apartheid}

Helman vokste opp i Sør-Afrika og var medisinstudent da kirurgen Christiaan Barnard (1922-2001) gjennomførte verdens første hjertetransplantasjon ved Groote Schuur Hospital i Cape Town i 1967. Han minnes denne hendelsen, og det slo ham at menneskets forhold til kroppen ville endres. Apartheidsystemet gjorde at han som student ble tvunget til å forholde seg til at svarte og hvite pasienter ble holdt atskilt i ulike avdelinger på universitetssykehuset. Han forteller om en pasient som oppsøkte sykehuset fordi han ble kastet av en buss som var forbeholdt hvite. Pasienten som egentlig var hvit, hadde fått økt pigmentering i huden pga. Addisons sykdom. Historien illustrerer at selv om en sykdom kan skyldes en biologisk svikt, vil den alltid fortolkes og håndteres innen en kulturell og politisk kontekst. Som turnuslege opplevde Helman en anestesilege som var motvillig til å gi en svart pasient generell anestesi i forbindelse med en kirurgisk revisjon av et stort sår. Helman protesterte, og med pasienten som tilhører på operasjonsbordet, ble man etter hvert enige om å innlede anestesi, med henvisning til at «gamle doktor Helman her liker ikke at vi er slemme mot dyr». Etter å ha gjennomført turnustjenesten valgte Helman å forlate Sør-Afrika pga. den politiske situasjonen i landet.

\section{Kompleksitet}

Helman flyttet til London i 1969, etablerte seg som allmennlege og drev praksis parallelt med sin akademiske virksomhet. I Suburban shaman byr han på sine observasjoner, skjerpet og fokusert gjennom antropologens briller, hvor han demonstrerer betydningen av at leger interesserer seg for pasienters fortolkning av egne helseplager. Dette er en viktig kompetanse, ikke minst i et flerkulturelt samfunn, fordi sykdomsoppfatningen betinger helseatferd og pasientens 
presentasjon av sine symptomer på legekontoret. En av anekdotene i boken handler om en eldre kvinne som oppsøker lege fordi hun opplever at det svømmer gullfisk i urinen hennes. Hvordan håndterer man en slik situasjon? Det er i møte med slike utfordringer Helman mener allmennmedisinen står i en særstilling i forhold til andre medisinske spesialiteter, ved at allmennlegen må ha kompetanse til å fortolke og forholde seg til kompleksiteten i sykdomsbildene slik de opptrer, uselektert, i det Helman betegner som «medisinens frontlinje».

\section{Usikkerhet}

I Suburban shaman viser Helman betydningen av at allmennlegen har en nøktern holdning til usikkerhet og har evne til å leve med flertydighet. Dette står i kontrast til den høyspesialiserte medisin som han mener i økende grad preges av reduksjonistiske tilnærminger og en streben etter å eliminere usikkerhet og flertydighet. Helman er ikke motstander av spesialisering og høyteknologi. Men, advarer han i boken, vi må huske at vi aldri vil kunne fjerne all usikkerhet knyttet til medisinsk praksis, og vi vil heller ikke kunne redusere kompleksiteten i menneskelig lidelse. Ifølge Helman er den høyspesialiserte medisinen i vestlige samfunn i ferd med å bli upersonlig og i for stor grad ha preg av en industri hvor man driver masseproduksjon av helsetjenester. Han maner til kamp mot det han karakteriserer som «legens indre demoner» - krefter som han mener bidrar til en negativ utvikling av faget: Frykten for å gjøre feil, frykten for å overse en diagnose, frykten for nærhet til pasienten og frykten for døden.

\section{Drabantbysjamanen}

Bokens tittel antyder en forbindelseslinje mellom den folkelige helbreder - sjamanen - og dagens allmennlege. Helmans ærend er ikke å romantisere folkelige helbredere, men han mener at de ofte viser evne til å ivareta pasienters grunnleggende behov. Dette kan være å lindre ubehag og engstelse, tilby et forhold preget av medfølelse og omsorg, gi en forklaring på hva som har gått galt og hvorfor, og bidra til å skape mening i pasientens lidelser. Å imøtekomme slike behov er en kjerneoppgave også i moderne medisin, men han mener den høyspesialiserte medisinen i for stor grad forsømmer denne oppgaven. Han skriver følgende med bakgrunn i sine egne erfaringer som pasient: «Nå er vi kun brukne bein, syke organer, samlinger av ustyrlige celler [...] Noe mangler. Kall det «person» eller til og med «ånd» eller «sjel», men hva det nå enn er så kan du ikke se det i mikroskopet eller oppdage det på et CT-bilde. Du kan ikke måle det eller ta bilde av det, og likevel er det alltid til stede.» Ifølge Helman er det allmennlegen som i størst grad forholder seg til det som likevel alltid er til stede - mennesket bak diagnosen. Allmenn-

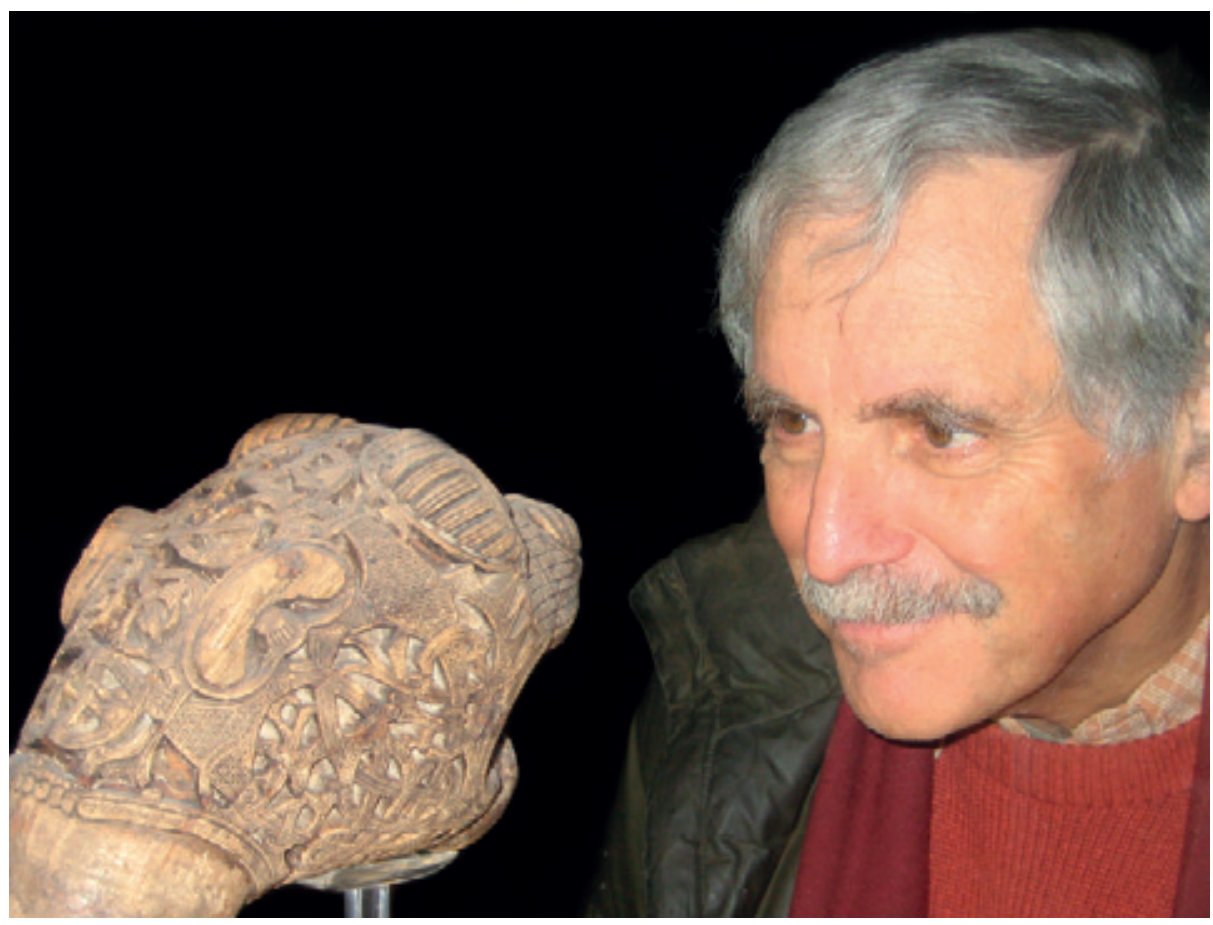

Cecil G. Helman (1944-2009) i nærkontakt med dyrehodestolpe fra Oseberggraven i Vikingskipshuset i Oslo, februar 2008. Foto Jan C. Frich

legene er på mange måter det moderne samfunnets sjamaner, mener han.

\section{Diskusjon}

I Suburban shaman demonstrerer Helman hvordan hverdagslivet er avgjørende for menneskers opplevelse og forløp av sykdom, og hvordan allmennlegen står i en nøkkelrolle som fortolker av dynamiske tegn og uttrykk som ikke kan telles og måles. Et av Helmans bidrag er å synliggjøre allmennlegens oppdrag og spesielle kompetanse knyttet til håndtering av kompleksitet og usikkerhet. Suburban shaman er således en påminnelse om hvorfor arbeidsmetodene og kunnskapsgrunnlaget i allmennmedisinen må være forskjellig fra arbeidsmetodene innen høyspesialisert medisin.

Noen kritiske merknader har vi likevel. Helman skriver av og til i større svart-hvittkontrast enn det som er nyttig for videre dialog. I sine beskrivelser av den høyspesialiserte medisinen kommer han med litt for enkle og generelle karakteristikker. Han maner til kamp mot våre indre demoner, men problematiserer i liten grad befolkningens forventninger og andre ytre krav til sikre og trygge helsetjenester - også i allmennmedisinen. Man kan dessuten stille spørsmål ved om det i dag er mulig å trekke et klart skille mellom illness og disease $\mathrm{i}$ en tid da pasienters sykdomsoppfatning i høyeste grad også utformes av medisinen selv.

\section{Avslutning}

Helman har vært en sentral bidragsyter til teoretisk nytenkning om medisinsk kunn- skap og praksis. Med sin kliniske forankring har han vært en effektiv brobygger, og har introdusert kulturkunnskap og pasientperspektiver som medisinske basalfag. Vi har opplevd Helmans publikasjoner som sentrale inspirasjonskilder for å forstå medisinen som et sett av kulturelle praksiser og som en fortolkningsvitenskap. I frontlinjen - mellom faget og hverdagslivet - ligger en viktig kilde til utvikling av ny kunnskap om sykdom og helse.

\section{Jan C. Frich}

Institutt for allmenn- og samfunnsmedisin og

Institutt for helseledelse og helseøkonomi Universitetet i Oslo

\section{Kirsti Malterud}

Allmennmedisinsk forskningsenhet Bergen Unifob helse

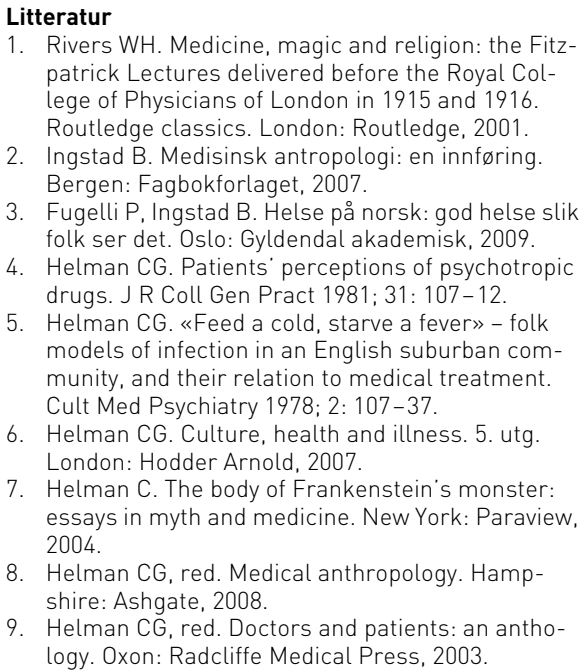

